\title{
Rевенгсн автісі: : Study of treatments and their interaction throughout poximate analysis in wheat, oat and barley crops
}

\author{
口 DEEPIKA VERMA AND ANITA DESHMUKH
}

Article Chronicle: Received : 17.07.2017;

Accepted :

01.08 .2017

KEY WoRds:

How to cite this article : Verma, Deepika and Deshmukh, Anita (2017). Study of treatments and their interaction Wheat, Oat, Barley, Protien, Cabohydrate, Fibre

SUMMARY : An experiment was conducted in Rabi season during 2012-2013 to find out the effect of cereal crops (Wheat, Oat, Barley) and cutting schedule on forage and grain yield. The study revealed the maximum chlorophyll accumulation in Barley and wheat during initial stage at 95 DAS and wheat and barley during reproductive stage at 30 DAS. Cutting at 50 DAS is proved beneficial on chlorophyll accumulation. Photosynthetic rate were maximum in wheat at 90 DAS. However, cutting did not affect photosynthesis rate stomatal conductance and transpiration rate. Barley gave maximum fodder yield (fresh/day). Cutting at 50 DAS was beneficial in producing maximum fodder yield without sacrificing grain yield of cereal crops.

throughout poximate analysis in wheat, oat and barley crops. Agric. Update, 12(TECHSEAR-6) : 1710-1714; DOI: 10.15740/HAS/AU/12. TECHSEAR (6)2017/1710-1714. 